\title{
The role of melatonin in the light of current knowledge
}

\section{Znaczenie melatoniny w świetle obecnej wiedzy}

\author{
Barbara Algiert', Helena Rotsztejn', Paulina Mucha², Ewa Trznadel-Grodzka ${ }^{3}$
}

'Department of Cosmetology and Aesthetic Dermatology, Faculty of Pharmacy, Medical University of Lodz, Lodz, Poland

2Department of Cosmetic Raw Materials Chemistry, Faculty of Pharmacy, Medical University of Lodz, Lodz, Poland

${ }^{3}$ Department of Dermatology, Pediatric and Oncological Dermatology, Faculty of Pharmacy, Medical University of Lodz, Lodz, Poland

KEY WORDS:

melatonin, metabolism, skin synthesis.

SŁOWA KLUCZOWE: melatonina, metabolizm, synteza skórna.

\author{
ADDRESS FOR \\ CORRESPONDENCE: \\ Barbara Algiert \\ Department of Cosmetology \\ and Aesthetic Dermatology \\ Medical University of Lodz \\ Lindleya 6 \\ 90-131 Lodz, Poland \\ Phone: +48 208127660 \\ E-mail: \\ barbara.algiert@umed.lodz.pl
}

\begin{abstract}
Recent studies have shed new light on the role of melatonin. Local tissue synthesis has been investigated. A special system responsible for the synthesis and metabolism of melatonin has developed in the human skin. The primary role of melatonin is the regulation of circadian rhythms, but studies have demonstrated the diversity of its activities. Potent antioxidant action of melatonin in the skin is emphasized. The skin has developed a specific antioxidant melatoninergic system which protects against oxidative stress. Presence of melatonin metabolites in the skin confirms its strong antioxidant properties. Melatonin has the ability to restore the physiological balance between synthesis and degradation of extracellular matrix proteins by induction of heme oxygenase in murine fibroblasts irradiated with UVR. There is a hypothesis concerning the participation of melatonin in etiology of vitiligo. Disturbances of melatonin skin synthesis and dysregulation of its receptors may explain the pathogenesis of disease.
\end{abstract}

\section{STRESZCZENIE}

Prowadzone w ostatnich latach badania rzucają nowe światło na rolę melatoniny. Wskazuje się na jej lokalną i tkankową syntezę. W skórze rozwinął się specjalny system, który odpowiada za syntezę oraz metabolizm melatoniny. Podstawową rolą melatoniny jest regulacja rytmu dobowego, jednak liczne badania wykazały różnorodność jej działania. Podkreśla się silne działanie antyoksydacyjne melatoniny w skórze, która rozwinęła specyficzny antyoksydacyjny system melatoninergiczny chroniący przed stresem oksydacyjnym. Obecność metabolitów melatoniny w skórze dodatkowo potwierdza jej silne właściwości antyoksydacyjne. Melatonina ma zdolność do przywracania równowagi fizjologicznej pomiędzy syntezą a rozpadem protein macierzy zewnątrzkomórkowej przez indukcję oksygenazy hemowej w mysich fibroblastach naświetlanych promieniowaniem UV. Istnieje hipoteza dotycząca udziału melatoniny w bielactwie nabytym, według której zaburzenia jej skórnej syntezy i rozregulowanie jej receptorów mogą tłumaczyć patogenezę tej choroby. 


\section{INTRODUCTION}

Over 50 years ago, melatonin (N-acetyl-5-methoxytryptamine) was isolated from the pineal gland, and was considered a hormone synthesized primarily by this organ. Melatonin was initially defined as a lightening factor of amphibians' skin due to its interaction with melanocytes. Subsequent years revealed that melatonin is present in the bodies of all vertebrates and is involved in regulation of the circadian rhythm and the annual cycle. Further studies have demonstrated its presence in many organisms such as bacteria, plants, invertebrates, and eukaryotes [1, 2].

The small size and lipophilic nature of the melatonin molecule make it easy to penetrate into intracellular structures, being thus their protector. It is now known that melatonin is a pleiotropic bioregulator. It participates in regulation of the immune response and inhibits tumor growth. Regardless of these characteristics, melatonin also has direct receptor-independent properties - it is a potent antioxidant, chemotoxic activity reducing agent in tumor treatment and a potential antiaging substance $[2,3]$.

Numerous studies have demonstrated the capacity of local tissue to synthesize melatonin. Cutaneous synthesis of melatonin occurs in the epidermis, dermis and skin appendages. Furthermore, the skin has the ability to metabolize this hormone. The resulting metabolites, in particular AFMK (N1-acetyl-N2formyl-5-methoxykynuramine), are extremely potent free radical scavengers [2-4]. Especially noteworthy is the antioxidant role of melatonin in the skin. Presumably due to UV radiation, the skin has developed a specific antioxidant melatoninergic system (MAS), which has a protective role against UV radiation-induced oxidative stress [2-4]. There is a hypothesis on the involvement of melatonin, and more specifically MAS, in the pathogenesis of vitiligo. Disturbances of cutaneous synthesis of melatonin can damage DNA in skin cells. This is connected with the strong antioxidant properties of the hormone. Abnormal cutaneous synthesis of melatonin may result in the absence or deficiency of the hormone. Radicals arising from the melanogenesis are not scavenged and their accumulation leads to melanocyte damage [5-7].

\section{CUTANEOUS SYNTHESIS OF MELATONIN}

The main biosynthetic pathway of melatonin, regardless of the type of cells in which melatonin is synthesized, is a series of enzymatic biochemical transformations (5-hydroxylation, decarboxylation, $\mathrm{N}$-acetylation, $\mathrm{O}$-methylation) whose onset is in one of the most important amino acids - L-tryptophan (1). The synthesis of melatonin can occur by alternative $O$-methylation of serotonin followed by
$\mathrm{N}$-acetylation of 5 methoxytryptamine, or $\mathrm{O}$-methylation and then decarboxylation of tryptophan and $\mathrm{N}$-acetylation [3-5].

Studies carried out on golden Syrian hamsters have demonstrated that the skin of rodents exhibits activity for AANAT (serotonin $\mathrm{N}$-acetyltransferase), a key enzyme in melatonin synthesis, and is able to convert serotonin into melatonin ex vivo. These findings have initiated a series of studies showing that the skin of other mammals (including humans) is capable of synthesis of this hormone. The process of creating melatonin in the skin is made possible by a high concentration of L-tryptophan molecules, which are the precursors necessary for melatonin biosynthesis. The cutaneous melatoninergic system includes gene expression, protein synthesis, previously mentioned AANAT activity and also hydroxyindole-O-methyltransferase (HIOMT) and tryptophan hydroxylase (TPH) with its isoforms TPH1 and TPH2 [3-5].

Melatonin biosynthesis (fig. 1) in the skin takes place in four stages:

1) L-tryptophan (1) in the presence of TPH undergoes hydroxylation to form 5-hydroxytryptophan (2) [3-5]. Tryptophan hydroxylase is located in the epidermis and in hair follicles and eccrine sweat glands. The highest expression of TPH is shown in melanocytes.

2) The second stage involves decarboxylation of 5-hydroxytryptophan (2) to serotonin (3) in the presence of aromatic amino acid decarboxylase (AAD).

3) Serotonin is then subjected to N-acetylation in the presence of alkylaryl-N-acetyltransferase (AANAT), thereby forming $\mathrm{N}$-acetylserotonin (4). This process occurs in epidermal and dermal cells and appendages.

4) The final step is $\mathrm{O}$-methylation of $\mathrm{N}$-acetylserotonin (4) involving hydroxyindole-O-methyltransferase (HIOMT), in which the final product, melatonin, is obtained (5) [3-5].

An alternative synthesis pathway of melatonin comprises acetylation of serotonin (3) in the presence of arylamine N-acetyltransferase (NAT), independent of AANAT. Detection of AANAT activity and immunoreactivity of melatonin in various layers of the human epidermis suggests that environmental factors such as sunlight can affect cutaneous synthesis of melatonin [3-5].

\section{MELATONIN RECEPTORS IN THE SKIN}

The mechanism of melatonin activity occurs through binding to intracellular proteins and also to membrane and nuclear receptors. The membrane receptors include MT1 (Mel 1a) and MT2 (Mel 1b) Mel 1; this group of receptors is $G$ protein-coupled. 
<smiles>NC(Cc1c[nH]c2ccc(O)cc12)C(N)Cc1c[nH]c2ccc(O)cc12</smiles><smiles>COc1ccc2[nH]cc(CCNC(C)=O)c2c1</smiles>

Melatonin (5)<smiles>CC(=O)NCCc1c[nH]c2ccc(O)cc12</smiles>

N-Acetyloserotonin (4)

Figure I. Melatonin synthesis

Rycina I. Synteza melatoniny

Mammalian skin exhibits dominant expression of MT1 receptors. They predominate in stratum granulosum and stratum spinosum cells. In pathological conditions, MT1 receptors are found in melanoma cells and squamous cell carcinoma $[1,3,8]$.

MT2 receptors are present in the inner coating of the hair, and their expression is associated with the hair growth cycle. In the case of MT2, UVB radiation can stimulate or modify their expression in melanocytes, keratinocytes and fibroblasts $[1,3,8]$.

Skin expression of MT1 and MT2 is also modified by genetic, pathological (tumor) and environmental factors, which include ultraviolet radiation (especially UVB) $[1,3,8]$.

Among the group of nuclear receptors, the subfamily of retinoid receptors retinoid orphan receptors/retinoid $Z$ receptors (ROR/RZR) can be distinguished. There are three main types of these receptors: $R O R \alpha, R Z R \beta$ and $R Z R \gamma$. Their expression has been found in the cells of various organs. The $\mathrm{ROR} \alpha$ receptor is present in the skin. Literature data indicate the possibility of oncostatic and immunomodulatory activities of nuclear receptors for melatonin $[1,3,8]$.

\section{METABOLISM OF MELATONIN IN THE SKIN}

The skin metabolism of melatonin includes the classical (indole) and enzymatic (kynurenine) pathway. A non-enzymatic UVB-induced pathway is a separate one $[3,4,6,9]$.

The indole pathway involves 6-hydroxylation of melatonin to form 6-hydroxymelatonin in the presence of CYP1A1, CYP1A2 or CYP1B1 (6) (fig. 2). The resulting compound is the major metabolite that can be found in the human body and may be bound by sulfates in the kidney, giving sulfatoxymelatonin, which is detectable in the urine $[3,4,6,9]$.<smiles>COc1ccc2[nH]cc(CCNC(C)=O)c2c1</smiles>

Melatonin (5)<smiles>COc1ccc2[nH]c(CCN)c(CN)c2c1</smiles>

5-Methoxytryptamine (7)<smiles>COc1ccc2[nH]cc(CC(=O)O)c2c1</smiles>

5-Methoxindoleacetic acid (9)<smiles>COc1ccc2[nH]cc(C=O)c2c1</smiles>

5-Methoxyindolealdehyde (8)

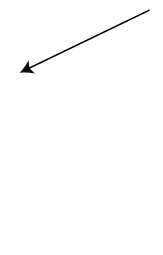<smiles>COc1ccc2[nH]cc(CCO)c2c1</smiles>

5-Methoxytryptophol (10)

Figure 2. The indole pathway of melatonin metabolism

Rycina 2. Szlak indolowy przemian melatoniny 


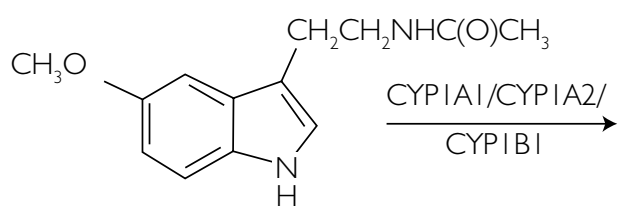

Melatonin (5)

Figure 3. Hydroxylation of melatonin

Rycina 3. Hydroksylacja melatoniny

The indole pathway includes the conversion of melatonin (5) to 5-methoxytryptamine (7), its oxidation (monoamine oxidase) to 5-methoxyindolealdehyde in the presence of MAO (8), and then conversion to 5-methoxyindoleacetic acid (9) by aldehyde dehydrogenase, or to 5-methoxytryptophol (10) by alcohol dehydrogenase (fig. 3).

The classical pathway is similar to the metabolic pathway of melatonin occurring in the cells of the liver, retina, and the skin of amphibians. Alternating cycles of melatonin caused by the action of reactive oxygen species or enzymes (i.e. 2,3-dioxygenase, methylperoxidase) lead mainly to obtaining 2- and 4-hydroxymelatonin and amino acid derivatives of kynurenic acid (AFMK, AMK) [3, 4, 6, 9].

\section{MELATONIN FUNCTIONS IN THE SKIN}

The skin is constantly exposed to the effects of harmful chemicals and physical agents. Defense mechanisms have been developed for preserving balance in its functioning. One of them is melanogenesis, which provides protection against UV radiation $[2,3]$. The production of melanin can be controlled by the local synthesis of melatonin. The extremely strong antioxidant properties of melatonin should be emphasized. Recently, the presence of the melatoninergic antioxidant system in the skin (MAS) has been demonstrated. This system includes the epidermis, dermis and hair follicles. It is likely that the MAS has evolved as a result of the defense mechanisms against environmental factors, in particular UV radiation [3, 10-15]. The antioxidant activity of melatonin is mediated by binding to nuclear receptors ROR/RZR and stimulation of gene expression of the main antioxidant enzymes (catalase, glutathione peroxidase). This hormone is a more effective antioxidant than glutathione and vitamins $\mathrm{E}$ and $\mathrm{C}$. In recent years, the presence of melatonin metabolites in the skin (AFMK, AMK) has been found. They arise, among other things, as a result of the non-enzymatic pathway (caused by UV radiation) [14]. This finding confirms not only the existence of metabolic pathway induced by UV, but also the already mentioned antioxidant activity. Melatonin in the skin reacts with hydroxyl radicals, resulting in the formation of 2-OH-melatonin and

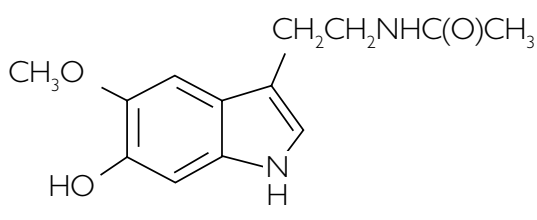

6-Hydroxymelatonin (6)
4-OH-melatonin, which are subsequently metabolized to AFMK. During this process, the hydroxyl radicals are scavenged, and the resulting adverse events are reduced directly or indirectly by reducing lipid peroxidation, protein oxidation, as well as mitochondrial and DNA damage. The melatonin metabolites AFMK and AMK are more potent free radical scavengers than melatonin itself [3, 12-16].

Potent antioxidant action of melatonin has been confirmed by the work of Eşrefoğlu et al. [17]. The study showed that the skin of pinealectomized rats was thinner than the skin of the animals in the control group. The authors point out that the lack of melatonin leads to defects in the extracellular matrix and the damaging effects of free radicals cause degradation of connective tissue proteins, which is associated with changes in skin thickness [17].

Recent studies indicate the ability of melatonin to restore the physiological balance between synthesis and degradation of extracellular matrix proteins by inducing heme oxygenase in murine fibroblasts irradiated with UVR [17]. It is known that UVA radiation induces oxidative stress in the cells, resulting in oxidation of cellular biomolecules such as DNA and lipids. Furthermore, it induces inflammation, activates phosphatases and protein kinases, and is responsible for the degradation of extracellular matrix components. In addition, UV radiation contributes significantly to premature aging of the skin. Harmful oxygen radicals which are formed during UV exposure have a devastating impact on the structure of the connective tissue. Fibroblasts play a crucial role in the processes of skin aging - they are responsible for the synthesis of extracellular matrix components such as collagen, glycosaminoglycans, and elastin. It has been observed that heme oxygenase 1 (HO-1) plays an important role in the protection of fibroblasts, and melatonin enhances the expression of this enzyme, which confirms its protective properties for cells [3, $12-16,18-21]$. Melatonin also plays an important oncostatic role through slowing the growth of tumors and inhibiting angiogenesis within them. Moreover, it exerts antiproliferative effects on tumor cells and enhances the immune response (production of interleukins). The oncostatic effect is inextricably linked with antioxidant action. Studies show the possibili- 
ty of using melatonin as adjunctive therapy, which would increase the effectiveness of chemotherapy and alleviate its course [22, 23]. Melatonin may also be used in cosmetics. Research was carried out using a cream which contained a multivitamin complex, melatonin, and the pure form of vitamin C (L-ascorbic acid - LAA) stabilized with resveratrol and Vitis vinifera [24]. The formulation was intended for application to the skin damaged by UV radiation, and the results showed an improvement in its thickness [24].

\section{MELATONIN AND VITILIGO}

After the isolation of melatonin, the hormone was applied to frog skin and caused its brightening. The mechanism of skin lightening was based on the induction of aggregation of melanosomes around the nuclei of melanophores. It is now known that melatonin exerts an inhibitory effect on melanogenesis by acting on tyrosinase. These interactions are not dependent on melatonin receptors, and are the result of metabolic reactions or an unbound receptor ligand $[6,7]$. Vitiligo deserves particular attention in the context of MAS, as it causes discoloration of the skin, due to damage of melanocytes. The exact mechanism of the disease is unknown. Theories about the pathogenesis of vitiligo focus on three mechanisms: autoimmune, autocytotoxic and associated with the nervous system. There is a hypothesis concerning the participation of melatonin in vitiligo. Considering the important antioxidant properties of melatonin, it is hypothesized that dysregulation of MAS may induce vitiligo and also lead to its progression. An insufficient amount or lack of local melatonin synthesis and thus the lack of its metabolite AFMK increases vulnerability of the epidermis to oxidative stress. Lack of melatonin, with simultaneous damage to melanocytes, can eventually lead to their death. It is also highly probable that the disturbances of melatonin receptor mechanisms inhibit the formation of melanin. Lack of melanin, which is a free radical scavenger, in conjunction with melanogenesis (in which toxic intermediates are formed), leads to the formation of cytotoxic radical forms. Disturbances of cutaneous synthesis of melatonin, as well as dysregulation of its receptors (which inhibit the production of melanin), may explain the pathogenesis of vitiligo. Hence a vicious circle arises during which oxygen radicals and hydrogen peroxide are produced, and their accumulation leads to further damage to cell DNA, contributing in this way to the disease [5].

\section{ACKNOWLEDGMENTS}

The study was supported by statutory research activity no. 503/3-066-01/503-31-001.

\section{Conflict of interest}

The authors declare no conflict of interest.

\section{References}

1. Danielczyk K., Dzięgiel P.: MT1 melatonin receptors and their role in the oncostatic action of melatonin. Post Hig Med Dosw 2009, 63, 425-434.

2. Slominski A.T., Kleszczyński K., Semak I., Janjetovic Z., Żmijewski M.A., Kim T.K. i inni: Local melatoninergic system as the protector of skin integrity. Int J Mol Sci 2014, 15, 17705-17732.

3. Słomiński A., Tobin D.J., Żmijewski M.A., Wortsman J., Paus R.: Melatonin in the skin: synthesis, metabolism and functions. Trends Endocrin Met 2008, 19, 17-24.

4. Moreno A.C., Clara R.O., Coimbra J.B., Júlio A.R., Albuquerque R.C., Oliveira E. i inni: The expanding roles of 1-methyl-tryptophan (1-MT): in addition to inhibiting kynurenine production, 1-MT activates the synthesis of melatonin in skin cells. FEBS J 2013, 280, 4782-4792.

5. Fischer T.W., Słomiński A., Żmijewski M.A., Reiter R.J., Paus R.: Melatonin as a major skin protectant: from free radical scavenging to DNA damage repair. Exp Dermatol 2008, 17, 713-730.

6. Hardeland R., Pandi-Perumal S.R., Cardinali D.P.: Melatonin. Int J Biochem Cell Biol 2006, 38 , 313-316.

7. Słomiński A., Tobin D.J., Shibahara S., Wortsman J.: Melanin pigmentation in mammalian skin and its hormonal regulation. Physiol Rev 2004, 84, 1155-1228.

8. Słomiński A., Fisher T., Żmijewski M.A., Wortsman J., Semak I., Zbytek B. i inni: On the role of melatonin in skin physiology and pathology. Endocrine 2005, 27, 137-148.

9. Kang-Tae K., Kleszczyński K., Janjetovic Z., Sweatman T., Zongtao L., Wei L. i inni: Metabolism of melatonin and biological activity of intermediates of melatoninergic pathway in human skin cells. FASEB J 2013, 27, 2742-2755.

10. Fischer T.W., Zbytek B., Sayre R.M., Apostolov E.O., Basnakian A.G., Sweatman T. i inni: Melatonin increases survival of $\mathrm{HaCaT}$ keratinocytes by suppressing UV-induced apoptosis. J Pineal Res 2006, 40, 18-26.

11. Fischer T.W., Żmijewski M.A., Wortsman J., Słomiński A.: Melatonin maintains mitochondrial membrane potential and attenuates activation of initiator (casp-9) and effector caspases (casp-3/casp-7) and PARP in UVR-exposed HaCaT keratinocytes. J Pineal Res 2008, 44, 397-407.

12. Iżykowska I., Piotrowska A., Podhorska-Okołów M., Cegielski M., Zabel M., Dzięgiel P.: The protective role of melatonin in the course of UV exposure. Post Hig Med Dosw 2008, 62, 23-27.

13. Kleszczyński K., Fischer T.W.: Melatonin and human skin aging. Dermatoendocrinol 2012, 4, 245-252.

14. Maharaj D.S., Anoopkumar-Dukie S., Glass B.D., Antunes E.M., Lack B., Walker R. i inni: The identification of the UV degradants of melatonin and their ability to scavange free radicals. J Pineal Res 2002, 32, 257-261.

15. Scheurer C., Pommergard H.C., Rosenberg J., Gogenur I.: Melatonin's protective effect against UV radiation: a systematic review of clinical and experimental studies. Photodermatol Photoimmunol Photomed 2014, 30, 180-188.

16. Galano A., Dun-Xian T., Reiter R.J.: On the free radical scavenging activities of melatonin's metabolites, AFMK and AMK. J Pineal Res 2013, 54, 245-257.

17. Eşrefoğlu M., Seyhan M., Gül M., Parlakpınar H., Batçıŏlu K., Uyumlu B.: Potent therapeutic effect of melatonin on aging skin in pinealectomized rats. J Pineal Res 2005, 39, 231-237. 
18. Fischer T.W., Kleszczyński K., Hardkop L.H., Kruse N. Zillikens D.: Melatonin enhances antioxidative enzyme gene expression (CAT, GPx, SOD), prevents their UVR-induced depletion, and protects against the formation of DNA damage (8-hydroxy-2'-deoxyguanosine) in ex vivo human skin. J Pineal Res 2013, 54, 303-312.

19. Desotelle J.A., Wilking M.J., Ahmad N.: The circadian control of skin and cutaneous photodamage. Photochem Photobiol 2012, 88, 1037-1047.

20. Fischer T.W., Żmijewski M.A., Zbytek B., Sweatman T.W., Słomiński A., Wortsman J.: Oncostatic effects of the indole melatonin and expression of its cytosolic and nuclear receptors in cultured human melanoma cell lines. Int J Oncol 2006, 29, 665-672.

21. Rezzani R., Rodella L.F., Favero G., Damiani G., Paganelli C., Reiter R.J.: Attenuation of ultraviolet A-induced

Received: $\quad 30$ III 2015

Accepted: 29 VI 2015 alterations in NIH3T3 dermal fibroblasts by melatonin. $\mathrm{Br}$ J Dermatol 2014, 170, 382-391.

22. Man'cheva T.A., Demidov D.V., Plotnikova N.A., Kharitonova T.V., Pashkevich I.V., Anisimov V.N.: Melatonin and metformin inhibit skin carcinogenesis and lipid peroxidation induced by benz(a)pyrene in mice. Bull Exp Biol Med 2011, 151, 363-365.

23. Slominski R.M., Reiter R.J., Schlabritz-Loutsevitch N., Ostrom R.S., Slominski A.T.: Melatonin membrane receptors in peripheral tissues: distribution and functions. Mol Cell Endocrinol 2012, 351, 152-166.

24. Tutino M., Bodian A., Oddenino R.: Melatonin cream and melatonin resveratrol LAA 15\% serum and quantum molecular resonance technology as ideal treatment for age related skin deseases. J Plast Surg 2010, 6, 133-140. 